\title{
PENGEMBANGAN MODUL PEMBELAJARAN IPA BERBASIS HIGH ORDER THINKING SKILL (HOTS) UNTUK MENINGKATKAN KEMAMPUAN BERPIKIR KRITIS SISWA KELAS VIII SMP/MTs
}

\author{
Emi Rofiah $^{1}$, Nonoh Siti Aminah ${ }^{2}$, Widha Sunarno $^{3}$ \\ ${ }^{1}$ Program Studi Magister Pendidikan Sains FKIP Universitas Sebelas Maret \\ Surakarta, 57126, Indonesia \\ emi.rofiah@student.uns.ac.id \\ ${ }^{2}$ Program Studi Magister Pendidikan Sains FKIP Universitas Sebelas Maret \\ Surakarta, 57126, Indonesia \\ nonohsitiaminah@staff.uns.ac.id \\ ${ }^{3}$ Program Studi Magister Pendidikan Sains FKIP Universitas Sebelas Maret \\ Surakarta, 57126, Indonesia \\ widhasunarno@staff.uns.ac.id
}

\begin{abstract}
Abstrak
Pembelajaran IPA masih belum banyak mengembangkan kemampuan berpikir tingkat tinggi siswa. Penelitian ini bertujuan untuk mendeskripsikan karakteristik modul pembelajaran IPA berbasis High Order Thinking Skill (HOTS) untuk meningkatkan kemampuan berpikir kritis, memperoleh modul pembelajaran IPA berbasis HOTS yang telah memenuhi kriteria layak, dan mengetahui peningkatan kemampuan berpikir kritis siswa kelas VIII SMP N 2 Sragen setelah melakukan pembelajaran IPA menggunakan modul pembelajaran IPA berbasis HOTS. Penelitian pengembangan modul pembelajaran IPA berbasis HOTS ini menggunakan prosedur pengembangan 4D yang terdiri dari tahap pendefinisian (define), perancangan (design), pengembangan (develop), dan penyebaran (dessiminate). Tahap pendefinisian terdiri dari proses analisis kebutuhan, analisis materi, serta perumusan pembelajaran pada modul. Tahap perancangan modul sesuai dengan tahap pendekatan saintifik yang diintegrasikan ke dalam modul. Tahap pengembangan terdiri dari proses validasi kelayakan modul, revisi, dan aplikasi modul pembelajaran IPA berbasis HOTS di kelas VIIIE SMP N 2 Sragen. Tahap penyebaran merupakan proses penyebaran modul ke empat SMP/MTS di Kabupaten Sragen. Analisis data pada tahap pendefinisian dilakukan secara deskriptif kuantitatif berdasarkan presentase jawaban angket. Pada tahap pengembangan, dilakukan analisis cut off score untuk menentukan kelayakan modul, analisis kriteria penilaian berdasarkan angket penilaian, analisis quest terhadap hasil uji coba instrumen tes, serta analisis gain score terhadap hasil pretest dan posttest. Pada tahap penyebaran dilakukan analisis kriteria penilaian berdasarkan hasil angket penilaian. Hasil penelitian disimpulkan bahwa: 1) karakteristik khusus modul pembelajaran IPA berbasis HOTS memiliki lima tahap pembelajaran sesuai dengan pendekatan saintifik yang dituangkan pada rubrik dalam modul; 2) modul pembelajaran IPA berbasis HOTS yang dikembangkan memenuhi kriteria kelayakan pada aspek isi dan penyajian, bahasa, kegrafikan, dan aspek pembelajaran HOTS dengan nilai rata-rata 3,55 atau dalam kategori "sangat baik"; 3) modul pembelajaran IPA berbasis HOTS dengan tema sistem penglihatan manusia dapat meningkatkan kemampuan berpikir kritis siswa dengan nilai gain 0,49 atau dalam kategori "sedang".
\end{abstract}

Kata Kunci: modul IPA, high order thinking skill, kemampuan berpikir kritis

\section{Pendahuluan}

Pendidikan menjadi aspek yang paling berpengaruh dalam upaya membentuk generasi bangsa yang siap menghadapi masalah-masalah di era globalisasi. Namun, kualitas pendidikan di Indonesia ternyata masih termasuk dalam kategori rendah. Hal ini terungkap melalui hasil survei Program for International 
Student Assessment (PISA) yang diadakan oleh Organization for Economic Cooperation and Development (OECD) dan Trends in Mathematics and Science Study (TIMSS) yang menunjukkan nilai kemampuan membaca sebesar 396, di bawah nilai rata-rata sebesar 496. Perolehan skor literasi sains sebesar 386, di bawah nilai rata-rata 501. Demikian pula hasil TIMSS yang diperoleh siswa Indonesia dengan nilai 397, di bawah nilai rata-rata 500. Rendahnya kemampuan membaca siswa dipengaruhi oleh beberapa faktor, misalnya kondisi bahan ajar. Seperti yang disarikan dari penelitian Pratama (2011) yang menyatakan bahwa kerumitan bahan ajar yang disampaikan semakin membuat siswa lemah dan malas dalam membaca pembelajaran IPA.

Salah satu bahan ajar yang dapat dikembangkan dengan penyampaian materi dan kegiatan belajar yang sederhana serta menarik minat siswa untuk belajar adalah modul. Keunggulan modul sebagai bahan ajar antara lain dapat dipelajari di berbagai tempat, mandiri atau tidak harus dipelajari secara berkelompok, serta dapat dipelajari secara fleksibel (Sungkono, 2003). Modul dapat dikembangkan sendiri oleh guru sesuai dengan kebutuhan dan karakteristik siswa. Guru sebagai unsur pendidikan yang terlibat langsung dalam pembelajaran di kelas dituntut untuk memiliki kompetensi dalam menggunakan dan mengembangkan bahan ajar.

Bahan ajar yang dikembangkan oleh guru tidak hanya mampu menarik minat baca dalam pembelajaran IPA, melainkan juga memuat kegiatan yang mampu mengembangkan kemampuan berpikir siswa. Hal ini sejalan dengan tujuan pembelajaran IPA yang dituangkan dalam standar isi SMP yang menyatakan bahwa pembelajaran IPA sebaiknya dilaksanakan secara inkuiri ilmiah (scientific inquiry) untuk menumbuhkan kemampuan berpikir, bekerja dan bersikap ilmiah serta mengkomunikasikannya sebagai aspek penting kecakapan hidup (BSNP, 2006:149). Namun, tujuan ini belum sepenuhnya tercapai karena kemampuan berpikir siswa pada tahap penerapan dan penalaran masih rendah.

Rendahnya kemampuan penalaran mengindikasikan rendahnya keterampilan berpikir tingkat tinggi (high order thinking skill - HOTS). HOTS merupakan proses berpikir yang tidak sekedar menghafal dan menyampaikan kembali informasi yang diketahui. Kemampuan berpikir tingkat tinggi merupakan kemampuan menghubungkan, memanipulasi, dan mentransformasi pengetahuan serta pengalaman yang sudah dimiliki untuk berpikir secara kritis dan kreatif dalam upaya menentukan keputusan dan memecahkan masalah pada situasi baru. Dalam konteks pembelajaran, berpikir tingkat tinggi terjadi ketika peserta didik mampu menghubungkan dan mentransformasi pengetahuan yang sudah dimilikinya dengan hal-hal atau masalahmasalah yang belum pernah diajarkan dalam pembelajaran. Keterampilan berpikir pada tingkat yang lebih tinggi tidak dapat diperoleh secara langsung sehingga perlu dilatihkan melalui kegiatan pembelajaran.

Salah satu kemampuan dalam keterampilan berpikir tingkat tinggi yang dapat ditingkatkan selama proses pembelajaran adalah kemampuan berpikir kritis. Astika, Suma \& Suastra (2013:3) dalam penelitiannya menyebutkan rendahnya berpikir kritis siswa terlihat dalam perilaku siswa yaitu rasa ingin tahu dalam mencari informasi masih rendah, siswa pasif dan hanya guru yang memberi informasi, siswa malu bertanya dan tidak berani mengungkapkan pendapat. Oleh karena itu, siswa perlu dilatih untuk mengembangkan kemampuan berpikir kritisnya melalui pembelajaran yang berbasis keterampilan berpikir tingkat tinggi yang dimuat dalam bentuk modul.

Berdasarkan studi pendahuluan yang dilakukan di SMP N 2 Sragen melalui kegiatan analisis kebutuhan diperoleh data $77,8 \%$ tidak memiliki sumber belajar cetak lain selain buku teks yang disediakan oleh sekolah. 100\% guru membutuhkan bahan 
ajar tambahan karena merasa buku teks yang disediakan sekolah memuat materi yang kurang lengkap. Hasil wawancara dengan siswa menunjukkan kurangnya kegiatan eksperimen dan diskusi karena guru hanya menjelaskan dan memberi pertanyaan yang bersifat matematis. Selain itu, berdasarkan angket sebanyak 33\% siswa merasa kesulitan dalam melakukan analisis data. Oleh karena itu, dibutuhkan solusi alternatif untuk mengatasi masalah kebutuhan siswa dan guru terhadap bahan ajar salah satunya dengan pembuatan modul pembelajaran berbasis HOTS.

Penelitian ini bertujuan untuk: 1) mendeskripsikan karakteristik modul pembelajaran IPA berbasis High Order Thinking Skill (HOTS) untuk meningkatkan kemampuan berpikir kritis; 2) memperoleh modul pembelajaran IPA berbasis HOTS yang telah memenuhi kriteria layak; dan 3) mengetahui peningkatan kemampuan berpikir kritis siswa kelas VIII SMP N 2 Sragen setelah melakukan pembelajaran IPA menggunakan modul pembelajaran IPA berbasis HOTS

\section{Metode Penelitian}

Penelitian ini merupakan penelitian pengembangan (research and development) yang bertujuan untuk mengembangkan modul pembelajaran IPA berbasis high order thinking skill (HOTS) untuk meningkatkan kemampuan berpikir kritis siswa. Model penelitian dan pengembangan modul pembelajaran IPA berbasis HOTS ini diadaptasi dari model 4-D (four- $D$ model) yang dikemukakan oleh Thiagarajan (1974:5). Model penelitian dan pengembangan ini meliputi tahap pendefinisian (define), perancangan (design), pengembangan (develop), dan tahap penyebaran (disseminate).

Pada tahap pendefinisian dilakukan analisis kebutuhan guru dan siswa, analisis materi, dan perumusan pembelajaran. Instrumen pengumpulan data yang digunakan pada tahap ini yaitu angket analisis kebutuhan guru dan siswa. Data dari angket dianalisis untuk mengetahui presentase jawaban. Selanjutnya, pada tahap perancangan dilakukan kegiatan pemilihan format, modul, perancangan pembelajaran dalam modul, dan desain awal modul. Pemilihan format modul disesuaikan dengan format modul menurut Depdiknas yaitu modul terdiri dari bagian pendahuluan, isi, dan penutup. Pembelajaran dalam modul dikemas dalam 4 kegiatan belajar (KB). Masing-masing $\mathrm{KB}$ terdiri dari tahap pembelajaran melalui pendekatan saintifik.

Pada tahap pengembangan dilakukan kegiatan uji coba instrumen tes latihan soal dan soal evaluasi, validasi modul, revisi I, uji coba skala kecil, uji coba instrumen tes kemampuan berpikir kritis revisi II, uji coba skala besar, dan revisi III. Validasi dilakukan oleh 1 orang ahli materi fisika, 1 orang ahli materi biologi, 1 orang ahli media, 1 orang ahli bahasa, 2 orang guru IPA, dan 2 orang teman sejawat. Instrumen yang digunakan pada tahap ini yaitu lembar validasi, lembar penilaian produk, dan instrumen tes kemampuan berpikir kritis. hasil uji coba instrumen tes dianalisis dengan program Quest untuk mengetahui reliabilitas, tingkat kesukaran, dan daya pembeda item. Data dari lembar validasi dan penilaian uji coba skala besar dianalisis dengan menghitung skor rata-rata kemudian dikategorikan sesuai kriteria penilaian menurut Azwar (2007). Kelayakan modul berdasarkan validasi dianalisis dengan metode natural cut off score. Peningkatan kemampuan berpikir kritis diketahui dari analisis $\mathrm{N}$-gain terhadap nilai pretest dan posttest siswa.

Pada tahap penyebaran, modul dan RPP diserahkan kepada 4 orang guru IPA SMP/MTs di Kabupaten Sragen untuk dinilai melalui instrumen berupa lembar respon dan penilaian produk. Analisis data dari lembar penilaian di tahap penyebaran ini sama dengan analisis data pada tahap validasi. 


\section{Hasil Penelitian dan Pembahasan}

\section{Hasil Penelitian}

Pada tahap pendefinisian dilakukan analisis kebutuhan guru untuk mengungkap kebutuhan guru terhadap ketersediaan modul pembelajaran IPA. Selain itu, analisis kebutuhan guru mengungkap pelaksanaan pembelajaran IPA khususnya implementasi pembelajaran berbasis HOTS. Hasil analisis kebutuhan guru disajikan pada Tabel 1.

Tabel 1. Hasil Analisis Kebutuhan Guru

\begin{tabular}{|c|c|}
\hline Indikator Pertanyaan & $(\%)$ \\
\hline 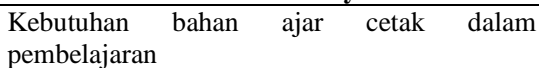 & 92 \\
\hline Kebutuhan tampilan bahan ajar yang menarik & 61 \\
\hline $\begin{array}{l}\text { Penerapan pembelajaran berbasis high order } \\
\text { thinking skills }\end{array}$ & 90 \\
\hline $\begin{array}{l}\text { Terdapat kendala dalam penyampaian materi } \\
\text { sistem penglihatan manusia }\end{array}$ & 75 \\
\hline
\end{tabular}

Analisis kebutuhan tidak hanya dilakukan terhadap guru, melainkan juga terhadap siswa. Sama seperti analisis kebutuhan guru, siswa juga diberi angket untuk mengungkap permasalahan yang dialami oleh siswa selama mengikuti proses pembelajaran IPA. Selain itu, juga dilakukan wawancara tidak terstruktur dengan beberapa siswa. Hasil analisis kebutuhan siswa disajikan dalam Tabel 2.

Tabel 2. Hasil Analisis Kebutuhan Siswa

\begin{tabular}{lc}
\hline \multicolumn{3}{c}{ Indikator Pertanyaan } & $\mathbf{( \% )}$ \\
\hline Kepemilikan bahan/sumber belajar & 22 \\
\hline $\begin{array}{l}\text { Kebutuhan akan bahan ajar cetak dalam } \\
\text { pembelajaran }\end{array}$ & 94 \\
\hline Kebutuhan tampilan bahan ajar yang menarik & 69 \\
\hline $\begin{array}{l}\text { Penerapan pembelajaran berbasis high order } \\
\text { thinking skills }\end{array}$ & 77 \\
\hline
\end{tabular}

Langkah selanjutnya yaitu analisis materi. Tema yang diangkat pada modul pembelajaran IPA berbasis HOTS ini adalah sistem penglihatan manusia. Pemilihan tema didasarkan pada rendahnya hasil UN siswa di Kabupaten Sragen pada materi optik. Tema disajikan dalam modul dengan model keterpaduan jaring laba-laba (webbed). Modul yang dikembangkan memuat 1 Standar kompetensi tentang penerapan getaran, gelombang, dan optika dalam produk teknologi sehari-hari serta 2 Kompetensi Dasar mengenai sifat-sifat cahaya dan alat optik.

Kebutuhan guru dan siswa terhadap bahan ajar cetak dalam pembelajaran IPA menjadi dasar pengembangan dan perancangan modul. Berdasarkan hasil wawancara diperoleh fakta bahwa penerapan HOTS belum maksimal sehingga modul pembelajaran dirancang menggunakan basis HOTS. Selain itu, baik guru, siswa, maupun sekolah juga belum memiliki bahan ajar yang berbasis HOTS. Padahal, dalam pembelajaran IPA khususnya materi sistem penglihatan manusia, siswa dapat mengamati, mengumpulkan informasi, dan menganalisis secara langsung karena materi yang dipelajari merupakan bagian dari tubuh manusia. Pembelajaran dalam modul disampaikan melalui tahap-tahap pendekatan saintifik yang memuat aspekaspek HOTS. Integrasi tahap saintifik dengan rubrik modul dapat dilihat pada Tabel 3

Tabel 3. Rubrik Modul

\begin{tabular}{cll}
\hline No & Tahap Saintifik & Rubrik dalam Modul \\
\hline 1 & Mengamati & Mari Mengamati ! \\
\hline 2 & Menanya & Ayo Bertanya! \\
\hline 3 & Mengumpulkan & Asyiknya \\
& Informasi & Mengumpulkan \\
& & Informasi! \\
\hline 4 & Menalar & Coba Pikirkan! \\
\hline 5 & Mengomunikasikan & Presentasi Yuk! \\
\hline
\end{tabular}

Tahap ketiga yaitu tahap pengembangan (develop) diawali dengan uji coba soal latihan yang terdapat dalam setiap akhir kegiatan pembelajaran serta uji coba instrumen tes evaluasi. Uji coba dilakukan terhadap 35 siswa kelas IX SMP N 2 Sragen. Hasil jawaban siswa selanjutnya dianalisis menggunakan program Quest untuk mengetahui item yang diterima, direvisi, dan ditolak yang ditinjau dari tingkat kesukaran serta daya pembeda item.

Selanjutnya, dilakukan validasi draft modul oleh ahli materi, ahli media, ahli bahasa, guru (reviewer), serta teman sejawat (peer reviewer). Hasil skor validasi 
yang disajikan diagram batang pada Gambar 1

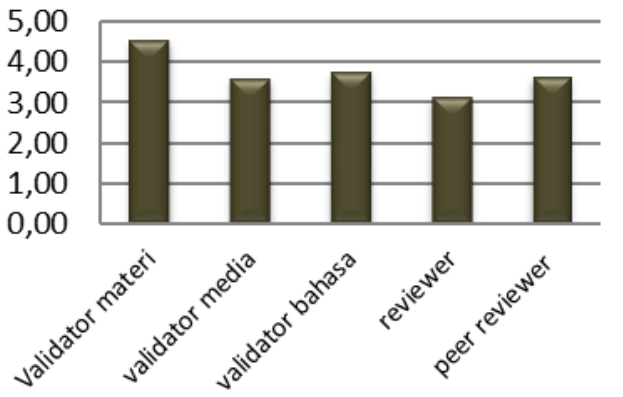

Gambar 1. Hasil Validasi Modul

Secara keseluruhan, skor yang diberikan oleh validator menunjukkan modul berada pada kategori sangat baik. Skor yang diberikan oleh para validator selanjutnya dianalisis prosentase keidealannya kemudian digunakan untuk menentukan kelayakan modul menggunakan metode natural cut off score. Modul dinyatakan memenuhi kriteria layak karena nilai rata-ratanya sebesar $85 \%$ lebih tinggi dari nilai minimum presentase keidealan modul yaitu $70 \%$.

Selain memberi skor melalui lembar kriteria, validator juga memberi komentar dan saran perbaikan terhadap draft modul. Revisi yang dilakukan terhadap draft modul berupa perbaikan gambar resolusinya rendah sehingga terlihat pecah, kesalahan pengetikan huruf, susunan kalimat yang tidak efektif, serta penambahan keterangan gambar.

Langkah selanjutnya yaitu dilakukan uji coba skala kecil. Modul diterapkan dalam pembelajaran oleh 16 siswa kelas IX. Setelah melaksanakan pembelajaran, siswa memberikan penilaian terhadap modul. Skor rata-rata yang diperoleh dari penilaian siswa terhadap keterbacaan modul pada uji kecil ini adalah 73,93 dan termasuk dalam kategori "Baik". Saran dan komentar siswa pada uji coba skala kecil digunakan sebagai bahan untuk melakukan revisi II.

Uji coba skala besar dilaksanakan terhadap 25 siswa kelas VIII SMP N 2 Sragen. Pembelajaran dilaksanakan sebanyak 4 kali pertemuan, Masing-masing pertemuan melaksanakan 1 kegiatan belajar. Respon siswa terhadap modul yang dituangkan dalam angket diperoleh skor rata-rata sebesar 75,64 sehingga modul termasuk dalam kategori "Sangat baik". Selanjutnya dilakukan perbaikan akhir terhadap modul berdasarkan saran yang diberikan oleh siswa pada uji coba skala besar.

Penilaian kemampuan berpikir kritis siswa dilakukan melalui kegiatan pretest dan posttest agar dapat diketahui nilai peningkatannya. Pretest diberikan pada siswa sebelum melaksanakan pembelajaran dengan modul pembelajaran IPA berbasis HOTS sedangkan posttest diberikan setelah siswa melaksanakan pembelajaran dengan modul. Peningkatan kemampuan berpikir kritis siswa dilihat dari nilai gain pada 12 indikator kemampuan berpikir kritis menurut Ennis. Skor gain masing-masing indikator disajikan pada Tabel 6 .

Tabel 6 N- gain Indikator Kemampuan Berpikir Kritis

\begin{tabular}{|c|c|c|c|}
\hline No & Indikator & $\begin{array}{c}N- \\
\text { gain }\end{array}$ & Kategori \\
\hline 1. & $\begin{array}{l}\text { Keterampilan } \\
\text { memfokuskan pertanyaan }\end{array}$ & 0,39 & Rendah \\
\hline 2. & Menganalisis argumen & 0,59 & Sedang \\
\hline 3. & $\begin{array}{l}\text { Bertanya dan menjawab } \\
\text { pertanyaan }\end{array}$ & 0,39 & Rendah \\
\hline 4. & $\begin{array}{l}\text { Menyesuaikan dengan } \\
\text { sumber }\end{array}$ & 0,41 & Sedang \\
\hline 5. & $\begin{array}{lr}\begin{array}{l}\text { Mengamati } \\
\text { melaporkan } \\
\text { observasi }\end{array} & \text { dan } \\
\end{array}$ & 0,56 & Sedang \\
\hline 6. & $\begin{array}{l}\text { Keterampilan } \\
\text { mempertimbangkan } \\
\text { kesimpulan }\end{array}$ & 0,43 & Sedang \\
\hline 7. & Melakukan generalisasi & 0,63 & Tinggi \\
\hline 8. & Melakukan evaluasi & 0,64 & Tinggi \\
\hline 9. & Mengartikan istilah & 0,25 & Rendah \\
\hline 10. & Membuat definisi & 0,55 & Sedang \\
\hline 11. & $\begin{array}{l}\text { Menentukan } \\
\text { tindakan }\end{array}$ & 0,53 & Sedang \\
\hline 12. & $\begin{array}{lr}\text { Berinteraksi } & \text { dan } \\
\text { berkomunikasi } & \text { dengan } \\
\text { orang lain } & \\
\end{array}$ & 0,46 & Sedang \\
\hline & Rata-rata N-gain & 0.49 & Sedang \\
\hline
\end{tabular}

Peningkatan tertinggi terjadi pada indikator melakukan evaluasi. Peningkatan terendah terjadi pada indikator mengartikan istilah. Namun, rata-rata skor $\mathrm{N}$-gain adalah 0,49 artinya terjadi peningkatan 
kemampuan berpikir kritis siswa pada kategori sedang setelah melaksanakan pembelajaran melalui modul pembelajaran IPA berbasis HOTS.

Peningkatan kemampuan berpikir kritis siswa dapat dilihat pula dari perbandingan rata-rata nilai pretest dan posttest seperti yang ditunjukkan melalui diagram pada Gambar 2.

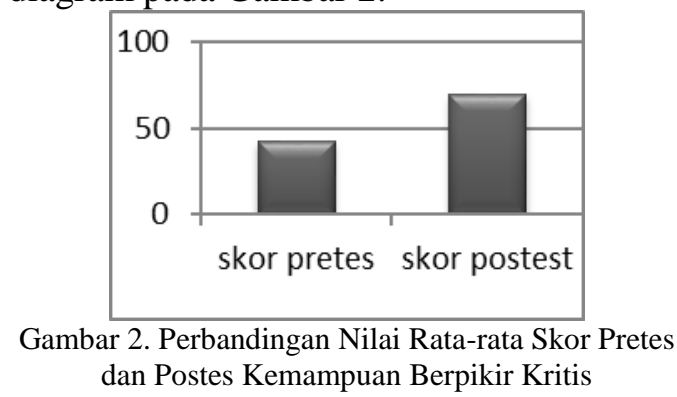

Hasil belajar siswa juga dinilai pada ranah kognitif, afektif, dan psikomotor. Pada ranah akognitif dinilai melalui tes evaluasi. Hasilnya, rata-rata nilai siswa adalah 77,1. Nilai ini lebih besar dibandingkan dengan KKM yaitu 75 . Ranah afektif yang dinilai yaitu rasa ingin tahu, ketelitian dan kehati-hatian, ketekunan dan tanggung jawab, serta keterampilan berkomunikasi. Hasilnya, terdapat peningkatan aspek afektif siswa dalam setiap pertemuan. Pada ranah psikomotor, dilakukan penilaian terhadap keterampilan merangkai alat, keterampilan menyusun data dalam tabel, serta keterampilan melakukan presentasi. Sama seperti hasil penilaian ranah afektif, aspek psikomotor siswa juga mengalami peningkatan.

Peningkatan hasil belajar siswa setelah belajar menggunakan modul IPA berbasis HOTS juga terlihat pada hasil penelitian oleh Winarno (2014). Dalam penelitian tersebut, penggunaan modul pembelajaran IPA berbasis HOTS dapat meningkatkan hasil belajar siswa. Namun, pembelajaran berbasis HOTS dalam penelitian tersebut disampaikan melalui model pembelajaran discovery learning serta tidak dikembangkan untuk meningkatkan kemampuan berpikir kritis siswa.
Tahap terakhir yaitu penyebaran (disseminate) yaitu menyebarkan modul kepada 4 orang guru yaitu guru SMP N 1 Sragen, SMP N 3 Sragen, SMP Muhammadiyah 1 Sragen, dan MTs Muhammadiyah 3 Masaran. Skor yang diberikan oleh para guru pada tahap ini disajikan dalam Tabel 9

\begin{tabular}{|c|c|c|c|c|}
\hline Responden & Skor & $\begin{array}{c}\text { Skor } \\
\text { maksi- } \\
\text { mal }\end{array}$ & $\begin{array}{c}\text { Skor } \\
\text { konversi }\end{array}$ & Kriteria \\
\hline 1 & 17 & 20 & 3,4 & $\begin{array}{l}\text { Sangat } \\
\text { Baik }\end{array}$ \\
\hline 2 & 18 & 20 & 3,6 & $\begin{array}{l}\text { Sangat } \\
\text { Baik }\end{array}$ \\
\hline 3 & 18 & 20 & 3,6 & $\begin{array}{l}\text { Sangat } \\
\text { Baik }\end{array}$ \\
\hline 4 & 18 & 20 & 3,6 & $\begin{array}{l}\text { Sangat } \\
\text { Baik }\end{array}$ \\
\hline Rata-rata & 17,75 & 20 & 3,55 & $\begin{array}{l}\text { Sangat } \\
\text { Baik }\end{array}$ \\
\hline
\end{tabular}

Skor rata-rata sebesar 17,75 yang diperoleh pada tahap penyebaran menempatkan modul pada kriteria sangat baik. Artinya, modul layak utuk digunakan dalam pembelajaran IPA.

\section{Pembahasan}

Produk utama yang dihasilkan dari penelitian ini adalah modul pembelajaran IPA berbasis high order thinking skill (HOTS). Penelitian dimulai dengan tahap pendefinisian yang terdiri dari kegiatan analisis kebutuhan guru, analisis kebutuhan siswa, analisis materi, dan perumusan kompetensi pembelajaran pada modul. Kegiatan-kegiatan tersebut dilakukan untuk mengungkap permsalahan yang terdapat dalam pembelajaran.

Analisis kebutuhan guru dilakukan melalui angket serta melalui wawancara tidak terstruktur secara langsung dengan guru. Hasil analisis kebutuhan guru mengungkap beberapa masalah yang terdapat dalam pelaksanaan pembelajaran IPA. Bahan ajar yang disediakan oleh sekolah kurang maksimal dalam memuat kegiatan praktikum serta latihan-latihan soal. Guru sangat membutuhkan bahan ajar cetak sebagai pelengkap dari bahan ajar yang disediakan sekolah. Bahan ajar 
berbentuk cetak dianggap lebih mampu memuat materi secara luas serta mudah dipelajari di rumah.

Guru telah merasa menerapkan beberapa aspek HOTS dalam pembelajaran. Namun, penerapan tersebut masih belum maksimal dan belum dapat mengembangkan keterampilan berpkir tingkat tinggi siswa. Para guru menganggap siswa kurang kritis selama pembelajaran. Siswa jarang bertanya, mengajukan pertanyaan tingkat rendah, serta pasif ketika hasil praktikum tidak sesuai dengan teori. Siswa juga kesulitan dalam melakukan analisis data. Berdasarkan hasil wawancara dengan siswa diketahui bahwa siswa jarang melakukan kegiatan eksperimen dan lebih banyak diajarkan untuk menyelesaikan soal-soal yang bersifat matematis. Hal ini dirasa kurang memaksimalkan kemampuan berpikir siswa dalam memahami konsep IPA yang tidak selalu bersifat matematis. Padahal, salah satu tujuan pembelajaran IPA di kelas menurut BSNP (2006) adalah melakukan inkuiri ilmiah untuk menumbuhkan kemampuan berpikir, bersikap dan bertindak ilmiah serta berkomunikasi.

Upaya untuk mengembangkan kemampuan siswa dalam bertindak ilmiah dapat ditunjang dengan melibatkan siswa dalam kegiatan eksperimen. Pembelajaran dengan melibatkan kegiatan eksperimen akan memberi pengalaman langsung pada siswa. Hal ini akan memberi dampak positif bagi siswa seperti yang dinyatakan dalam penelitian oleh Listyawati (2012) bahwa pengalaman belajar yang lebih menunjukkan kaitan unsur-unsur konseptual akan menjadikan proses belajar lebih efektif. Pemilihan basis HOTS sebagai basis pembelajaran dalam modul ini didasarkan pada teori perkembangan Piaget yang dikemukakan oleh Sulistyorini (2009) menyatakan bahwa siswa SMP dengan rentang usia antara 13-16 tahun telah masuk dalam tahap operasional formal dimana siswa sudah dapat menggunakan logikanya sehingga diharapkan siswa mampu mengikuti pembelajaran IPA berbasis HOTS.

Tahap selanjutnya yaitu analisis materi. Tema yang diangkat pada modul pembelajaran IPA berbasis HOTS ini adalah sistem penglihatan manusia. Materi disajikan secara terpadu dengan model keterpaduang jarring laba-laba (webbed). Penyajian materi secara tematik melalui model webbed diharapkan mampu meningkatkan ketertarikan siswa untuk belajar. Model keterpaduan webbed juga digunakan dalam penelitian oleh Yannurdanti (2013) karena model keterpaduan webbed dapat dikembangkan melalui suatu tema yang lebih luas yang menghubungkan jaringan dari berbagai disiplin ilmu sehingga siswa memperoleh pengalaman belajar.

Tema yang diangkat dalam modul pembelajaran IPA ini adalah sistem penglihatan manusia. Dalam UN, SKL yang memuat tema ini hampir selalu menempati peringkat bawah dari segi daya serap SKL pada hampir seluruh SMP di Kabupaten Sragen tahun ajaran 2013/2014. Tema ini mencakup dua materi dalam pembelajaran IPA, yaitu sifat-sifat cahaya dan alat optik. Tema sistem penglihatan manusia juga dirasa menarik berkaitan erat dengan indera yang setiap hari digunakan oleh manusia. Hal ini sesuai dengan yang disampaikan oleh Pusat Kurikulum (2006) yang menyatakan bahwa tema yang familiar akan membuat motivasi belajar meningkat. Namun, ternyata observasi di lapangan menunjukkan banyak siswa yang belum memahami bagian-bagian serta cara kerja sistem penglihatan manusia.

Tahap kedua dalam penelitian ini adalah tahap perancangan (design). Pada tahap ini dilakukan kegiatan pemilihan format yang terdiri dari 3 bagian antara lain bagian pendahuluan, isi, dan penutup. Modul terbagi dalam $4 \mathrm{~KB}$ yaitu $\mathrm{KB} 1$ membahas bagian-bagian mata, KB 2 membahas proses melihat, KB 3 membahas pembiasan pada lensa cembung, dan KB 4 membahas kerusakan pada mata. Setiap KB memuat tahap saintifik yang diintegrasikan 
dengan rubrik-rubrik dalam modul sehingga dapat menunjukkan karakteristik modul pembelajaran IPA yang dikembangkan. Implementasi HOTS dalam pembelajaran tidak memiliki sintaks tertentu sehingga dituangkan melalui tahapan pendekatan saintifik. Hal ini sesuai dengan pendapat Winarno (2014) yang menyatakan bahwa proses belajar menganalisis, mengevaluasi, dan mencipta yang merupakan komponen HOTS boleh dilaksanakan secara acak dalam proses pembelajaran.

Pembelajaran dalam modul disampaikan melalui tahap-tahap pendekatan saintifik yang memuat aspekaspek HOTS. Penerapan pendekatan saintifik diharapkan dapat mengembangkan kemampuan berpikir kritis siswa serta meningkatkan hasil belajarnya. Penerapan pendekatan saintifik pada pembelajaran melalui modul sejalan dengan penelitian oleh Lestari (2015) yang menghasilkan kesimpulan modul IPA terpadu dengan pendekatan saintifik dapat meningkatkan kemampuan siswa pada aspek pengetahuan, sikap, dan keterampilan.

Kelayakan modul pembelajaran IPA yang dikembangkan dalam penelitian ini diuji melalui serangkaian proses pada tahap ketiga penelitian, yaitu tahap pengembangan (develop). Pada tahap ini dilakukan uji coba latihan soal dan uji coba instrumen tes dalam modul yang dikembangkan berdasarkan indikatorindikator pembelajaran dalam setiap KB. Selanjutnya, dilakukan proses validasi ahli, guru, dan teman sejawat untuk mengetahui kelayakan modul. Thiagarajan (1974) mengemukakan bahwa pada tahap pengembangan, terdapat kegiatan penilaian ahli yang dilakukan untuk memperoleh saran serta perbaikan materi dalam produk yang dikembangkan.

Secara keseluruhan, skor yang diberikan oleh validator menunjukkan modul berada pada kategori "sangat baik". Artinya, modul IPA berbasis HOTS yang dikembangkan telah memenuhi aspek kedalaman materi yang baik, pembelajaran di dalam modul sesuai dengan pendekatan saintifik yang memuat aspek HOTS, memiliki desain kulit dan isi modul yang menarik, serta bahasa yang digunakan dalam modul bersifat komunikatif dan sesuai denga kaidah bahasa Indonesia. Berdasarkan hasil analisis diperoleh nilai natural cut off score sebesar 83 yang artinya modul layak untuk digunakan dalam pembelajaran karena nilai tersebut lebih tinggi dari skor batas bawah yaitu 70. Saran dan komentar yang diperoleh pada tahap validasi digunakan sebagai bahan untuk melakukan revisi I.

Selanjutnya dilakukan uji coba skala kecil. Skor rata-rata yang diperoleh dari penilaian siswa terhadap keterbacaan modul pada uji kecil ini adalah 73,93 dan termasuk dalam kategori "Baik". Artinya, menurut siswa modul pembelajaran IPA berbasis HOTS yang dikembangkan telah memiliki penyampaian materi yang lengkap dan sesuai aspek HOTS, bahasa yang mudah dimengerti, serta tampilan yang menarik. Selain memberi penilaian, siswa yang mengikuti uji coba skala kecil juga memberi saran dan komentar terhadap modul yang telah digunakan sebagai bahan untuk revisi guna meningkatkan kualitas modul.

Penilaian yang diberikan oleh siswa pada uji coba skala besar dengan skor ratarata sebesar 75,64 menempatkan siswa dalam kategori "sangat baik". Artinya, siswa menganggap modul pembelajaran IPA berbasis HOTS dianggap mampu menyajikan materi yang mudah dipahami, disampaikan dengan bahasa yang mudah dipahami, serta menyajikan tampilan layout dan gambar yang menarik. Beberapa siswa memberi saran untuk melakukan revisi pada kolom "Tugas" pada KB 1 yang dianggap terlalu sulit untuk dijawab. Setelah dilakukan revisi terakhir, diperoleh produk akhir berupa modul pembelajaran IPA berbasis HOTS dengan tema sistem penglihatan manusia.

Tahap terakhir dari penelitian ini adalah tahap penyebaran (disseminate). Penyebaran dilakukan terhadap 4 SMP/MTs di Kabupaten Sragen. Skor yang 
diberikan oleh masing-masing guru dari 4 sekolah tersebut memberikan hasil rata-rata sebesar 17,75 yang berarti modul termasuk dalam kriteria "sangat baik". Dengan demikian, modul pembelajaran IPA berbasis HOTS yang dikembangkan dalam penelitian ini telah layak dan sesuai untuk digunakan dalam pembelajaran.

Tujuan ketiga dari penelitian ini adalah untuk mengetahui besarnya peningkatan kemampuan berpikir kritis siswa setelah mengikuti pembelajaran menggunakan modul pembelajaran IPA berbasis HOTS. Kemampuan berpikir kritis siswa diukur melalui tes tertulis pada kegiatan pretest dan posttest. Pretest dilakukan sebelum siswa mengikuti pembelajaran menggunakan modul, sedangkan posttest dilakukan setelah siswa selesai mengikuti pembelajaran menggunakan modul.

Instrumen tes berupa soal pilihan ganda dengan empat pilihan jawaban. Itemitem soal dikembangkan berdasarkan 12 indikator kemampuan berpikir kritis menurut Ennis (1985). Jumlah soal yang terdapat pada instrumen tes kemampuan berpikir kritis yang digunakan adalah 22 . Hampir semua indikator diwakili oleh 2 item tes, kecuali untuk indikator kemampuan memfokuskan pertanyaan dan indikator mengartikan istilah. Peningkatan kemampuan berpikir kritis dilihat dari nilai $\mathrm{N}$-gain. Semakin besar nilai N-gain, artinya semakin besar pula peningkatan kemampuan berpikir kritis siswa.

Peningkatan tertinggi terjadi pada indikator melakukan evaluasi yaitu sebesar 0,64 . Item soal yang mewakili indikator ini berupa pertanyaan mengenai pembiasan cahaya jika melewati dua medium yang berbeda dan pembiasan pada lensa cembung. Kedua materi tersebut dipelajari siswa secara langsung dengan melakukan percobaan yang terdapat dalam modul, sehingga siswa lebih paham. Sedangkan peningkatan terendah terjadi pada indikator mengartikan istilah yaitu sebesar 0,25 . Item soal yang mewakili indikator tersebut berupa pertanyaan mengenai istilah "mata minus" yang sulit dikaitkan dengan konsep mata miopi dan lensa cekung sehingga item ini mendapat nilai yang rendah.

Skor rata-rata $\mathrm{N}$-gain sebesar 0,49 yang berarti peningkatan kemampuan berpikir kritis siswa termasuk dalam kategori "sedang". Peningkatan ini sejalan dengan hasil penelitian oleh Adi (2015) yang menujukkan bahwa pembelajaran dengan menggunakan modul dapat meningkatkan kemampuan berpikir kritis siswa.

Selain kemampuan berpikir kritis, ternyata modul pembelajaran IPA berbasis HOTS yang dikembangkan juga meningkatkan hasil belajar siswa pada tiga ranah yaitu kognitif, afektif, dan psikomotor. Pada ranah kognitif, rata-rata nilai siswa yang diperoleh dari tes evaluasi adalah sebesar 77,1. Nilai ini lebih tinggi dibandingkan dengan KKM yang ditetapkan sekolah untuk mata pelajaran IPA yaitu 75. Hal ini berarti, modul pembelajaran IPA berbasis HOTS telah cukup efektif dalam meningkatkan kemampuan berpikir siswa. Meskipun demikian, masih terdapat 8 siswa dengan nilai dibawah KKM sehingga perlu mengikuti kegiatan remidi.

Pada ranah afektif, penilaian dilakukan pada aspek rasa ingin tahu, ketelitian dan kehati-hatian, ketekunan dan tanggung jawab, serta keterampilan berkomunikasi. Hasilnya, ada peningkatan aspek afektif siswa dalam setiap pertemuan. Meskipun demikian, terdapat penurunan skor pada pertemuan ke empat yiatu pada aspek rasa ingin tahu dan aspek ketelitian dan kehati-hatian. Pertemuan ke empat membahas tentang kerusakan mata yang berisi kegiatan wawancara terhadap penderita kerusakan mata. terbatasnya jumlah narasumber menyebabkan tidak semua siswa antusias untuk bertanya atau menggali informasi karena merasa sudah diwakili oleh pertanyaan teman satu kelompoknya. Pada ranah psikomotor, dilakukan penilaian terhadap keterampilan merangkai alat, keterampilan menyusun data dalam tabel, serta keterampilan 
melakukan presentasi. Peningkatan terendah terjadi pada aspek keterampilan merangkai alat yaitu sebesar 0,20. Tidak setiap kegiatan pembelajaran dalam modul melibatkan kegiatan praktikum. Hal ini yang menyebabkan keterampilan siswa dalam merangkai alat tidak mengalami banyak peningkatan dibanding aspek keterampilan menyusun data dalam tabel serta melakukan presentasi.

\section{Kesimpulan dan Rekomendasi}

\section{Kesimpulan}

Kesimpulan yang diperoleh dari penelitian pengembangan ini antara lain:

1. Karakteristik khusus pengembangan modul pembelajaran IPA berbasis high order thinking skill (HOTS) dengan tema sistem penglihatan manusia yang dikembangkan oleh peneliti memiliki lima tahap pembelajaran sesuai dengan pendekatan saintifik yang dituangkan pada rubrik dalam modul. Rubrik tersebut antara lain: (1) Rubrik "Mari Mengamati!" yang memuat tahap mengamati; (2) Rubrik "Ayo Bertanya!" yang memuat tahap menanya; (3) rubrik "Asyiknya Mengumpulkan Informasi!" yang memuat tahap mengumpulkan informasi; (4) rubrik "Coba Pikirkan!" yang memuat tahap menalar; dan (5) rubrik "Presentasi Yuk!" yang memuat tahap mengomunikasikan

2. Modul pembelajaran IPA berbasis HOTS divalidasi oleh validator ahli materi, ahli media, ahli bahasa, guru, dan teman sejawat. Aspek kelayakan isi dan penyajian termasuk kategori "sangat baik" dengan skor 4,55. Aspek kelayakan kegrafikan termasuk kategori "sangat baik" dengan skor 3,60. Aspek kelayakan bahasa termasuk dalam kategori "sangat baik" dengan skor 3,75. Aspek materi, bahasa, tampilan, dan gambar termasuk dalam kategori "sangat baik" dengan skor 3,15 dari guru dan 3,65 dari teman sejawat. Hasil respon dan keterbacaan modul pada uji coba skala kecil menempatkan modul pada kategori "baik" dengan skor rata-rata 3,21 . Hasil respon siswa pada uji coba skala besar menempatkan modul dalam kategori "sangat baik" dengan skor 3,28. Hasil respon dan keterbacaan oleh guru dalam tahap penyebaran menempatkan modul pada kategori "sangat baik" dengan skor 3,55. Kriteria layak menurut uji coba skala kecil, uji coba skala besar, serta penyebaran sama dengan kriteria layak menurut reviewer dan peer reviewer. Hasil tersebut menujukkan bahwa modul pembelajaran IPA berbasis HOTS dengan tema sistem penglihatan manusia layak digunakan untuk digunakan dalam pembelajaran.

3. Modul pembelajaran IPA berbasis HOTS dengan tema sistem penglihatan manusia dapat meningkatkan kemampuan berpikir kritis siswa. Hal ini dapat dilihat dari peningkatan skor ratarata yang meningkat dari sbelum menggunakan modul (pretest) dengan setelah menggunakan modul (posttest) dengan nilai gain 0,49 yang termasuk dalam kategori sedang.

\section{Rekomendasi}

Berdasarkan kesimpulan dan pembahasan, maka terdapat saran sebagai pertimbangan perbaikan produk pada penelitian selanjutnya

1. Perlu adanya persiapan (terutama dari segi alokasi waktu) sebelum dilakukan pembelajaran menggunakan modul pembelajaran IPA berbasis HOTS agar pembelajaran terlaksana sesuai dengan RPP.

2. Modul yang dihasilkan dapat digunakan sebagai bahan ajar dalam pembelajaran. Namun, keterampilan guru dalam mengembangkan modul sesuai kebutuhan lapangan yang beragam sangat dibutuhkan agar diperoleh modul dengan kualitas yang baik.

3. Guru diharapkan dapat membuat menerapkan model pembelajaran yang bervariasi karena HOTS tidak hanya dapat dilatihkan melalui pendekatan saintifik. 
4. Diharapkan adanya rancangan pembelajaran yang dapat mengajak siswa untuk berinteraksi langsung dengan penderita kerusakan mata agar siswa memperoleh lebih banyak informasi dari sumber yang berpengalaman.

5. Hasil penelitian ini dapat digunakan sebagai acuan untuk mengembangkan penelitian sejenis, terutama penelitian pengembangan modul pembelajaran berbasis high order thinking skill yang masih sedikit dilakukan. Peneliti dapat mengembangkan modul dengan pendekatan dan materi atau tema yang berbeda.

\section{Daftar Pustaka}

Adi, D. W. (2015). Pengembangan Modul Fisika Berbasis Discovery Learning dengan Pendekatan Problem based Learning untuk Meningkatkan Kemampuan Berpikir Kritis dan Kreatif Siswa Kelas XI SMA/MA di Surakarta. Tesis, Universitas Sebelas Maret

Astika I. Kd. U, Suma I. K, \& Suastra I. W. (2013). Pengaruh Model pembelajaran Berbasis masalah terhadap Sikap Ilmiah dan Keterampilan berpikir Kritis. e-Journal Program Pascasarjana Universitas Pendidikan Ganesha, vol 3 tahun 2013. Diakses pada 16 Sepetember 2015 dari http://pasca.undiksha.ac.id/ejournal/index.php/jurnal_ipa/article/do wnload/851/606

Azwar, S. (2007). Penyusunan Skala Psikologi. Yogyakarta: Pustaka Pelajar Offset

Badan Standar Nasional Pendidikan. (2006). Standar Isi untuk Satuan Pendidikan Dasar dan Menengah: Standar Kompetensi dan Kompetensi Dasar SMP/MTs. Jakarta: BSNP

Departemen Pendidikan Nasional. (2008). Panduan Pengembangan Bahan Ajar. Jakarta: Depdiknas

Ennis, R. H. (1985). A Logical Basis for Measuring Critical Thinking Skill.
Diunduh dari http://www.ascd.org/ASCD/pdf/journal s/ed_lead/el_198510_ennis.pdf pada tanggal 16 Septembr 2015

Lestari. (2015). Pengembangan Modul IPA Terpadu dengan Pendekatan Saintifik Tema Sampah untuk Siswa Kelas VII SMP/MTs. Tesis. Universitas Sebelas Maret Surakarta

Listyawati, M. (2012). Pengembangan Perangkat Pembelajaran IPA Terpadu di SMP. Journal of Innovative Science Education (1) (2012) ISSN 2252-6412. Diunduh dari http://journal.unnes.ac.id/sju/index.php /jise/article/download/46/35 pada 6 Agustus 2016

Martin, M. O., .Mullis, V.S.I., Foy, P., Stanco, G. M. (2012). TIMSS 2011 International Results in Science. United States: TIMSS \& PIRLS International Study Center

OECD. (2014). PISA 2012 Result: What Students Know and Can Do - Student Performance inMathematics, Reading and Science (Volume I, Revised Edition, February 2014). OECD Publishing

Pratama, H. (2014). Pengembangan Modul Pembelajaran IPA Fisika SMP Kelas IX Berbasis Pendekatan Jelajah Alam Sekitar (JAS) pada Materi Gerakan Bumi dan Bulan yang Terintegrasi Budaya Jawa. Tesis. Universitas Sebelas Maret Surakarta

Pusat Kurikulum. (2006). Panduan pengembangan pembelajaran IPA Terpadu. Jakarta: Balitbang Depdiknas

Sulistyorini. (2009). Evaluasi Pendidikan dalam Meningkatkan Mutu Pendidikan. Yogyakarta: Penerbit TERAS

Thiagarajan, S., Semmel, D. S., \& Semmel, M. I. (1974). Instructional Development for Training Teachers of Exceptional Children. Minnesota: Center for Innovation in Teaching the Handicapped

Winarno. (2014). Pengembangan Modul IPA Terpadu Berbasis High Order Thinking Skill (HOTS) pada Tema Energi. Tesis, Universitas Sebelas Maret 
Yannurdanti, P. (2013). Peningkatan Efektifitas

Pembelajaran IPA Terpadu melalui Penggunaan Modul Berbasis Salingtemas Materi Cahaya dan Mata dengan Tema Cahaya dan Manfaatnya. Tesis. Universitas Sebelas Maret Surakarta 